\title{
Learning environment and primary school efficiency
}

A DEA bootstrap truncated regression analysis

\author{
Boon L Lee, Andrew Worthington, Clevo Wilson,
}

\begin{abstract}
Purpose - Existing studies of school efficiency primarily specify teacher inputs as the number of teachers and perhaps the student-teacher ratio. As a result, there is no direct qualitative recognition of the learning environment. The novel approach here is to incorporate the learning environment directly into the assessment of school efficiency.
\end{abstract}

Design/methodology/approach - We employ data envelopment analysis (DEA) to derive efficiency scores and the double bootstrap truncated regression approach in Simar and Wilson (2007) Journal of Econometrics to quantify the sources of efficiency in 430 Queensland state primary schools. In the first stage, the outputs of student National Assessment Program - Literacy and Numeracy (NAPLAN) scores and the inputs of full-time equivalent (FTE) teaching staff and cumulative capital expenditure per student are used to measure efficiency. In the second stage, we specify an index of community socio-educational advantage, class size, the share of teachers with postgraduate qualifications, funds spent on professional development, and surveyed opinions from parents/caregivers, students, staff and principals on the learning environment to explain these measures of efficiency.

Findings - Socio-economic background and the teaching environment affect school efficiency. Although not all variables related to teacher contribution are significant, there is evidence to suggest that teachers have a positive influence on student performance hence school efficiency. Teachers ability to clearly explain the requirements of schoolwork tasks and listening to student opinions sets an ideal student engagement environment which can have a profound impact on student learning.

Practical implications - From a policy perspective, policymakers should target resources at inefficient schools aimed at enhancing student learning through teacher development and at the same time providing financial and non-financial educational assistance to students and their families from a low socio-educational background.

Originality/value - First large-scale primary school efficiency analysis to incorporate the Simar and Wilson (2007) approach to explaining the determinants of efficiency, including teaching environment from the perspective of students, teachers, and other stakeholders.

Keywords Efficiency measurement, data envelopment analysis, bootstrap truncated regression, student learning, primary school

Paper type Research paper 


\section{Introduction}

Understanding how to improve primary school performance is a key challenge for many, and not least, governments as the principal operators and funders of primary school education in most developed and developing countries. In response, the last few decades have seen the worldwide implementation of a number of national policies and/or national assessment programs aimed at improving student outcomes. These include, among others, the 2001 No Child Left Behind Act in the US, the Italian Istituto Nazionale per la Valutazione del Sistema Educativo di Istruzione e di Formazione (National Institute for the Educational Evaluation of Instruction and Training), and the 2011 Gonski Inquiry and 2008 National Assessment Program-Literacy and Numeracy (NAPLAN) in Australia. They also include the 1988 Education Reform Act in the UK, the 1990 Sistema Nacional de Avaliação da Educação Básica (National System to Evaluate Basic Education) in Brazil, and the 2006 Compulsory Education Law of the People's Republic of China. At the same time, there has been a resurgent interest in the use of efficiency analysis to evaluate the performance of primary schools in relation to these student outcomes. Worthington (2001) and De Witte and López-Torres (2017) provide comprehensive reviews of the literature.

The extant literature typically uses data envelopment analysis (DEA) or stochastic frontier analysis (SFA) to measure school performance in the form of efficiency - the ability to maximise (minimise) outputs (inputs) for a given set of inputs (outputs). A significant number have subsequently employed second-stage regression analysis to regress the resulting efficiency scores obtained to determine the sources of efficiency and hence specific policy recommendations. Some of the more common second-stage regression methods used include ordinary least squares (OLS), the Tobit model, and the maximum likelihood bootstrap approach. Table 1 provides a summary of selected school efficiency studies in the past ten years that have employed second-stage regression analysis. 


\section{$<$ INSERT TABLE I HERE $>$}

The studies in Table 1 clearly suggest that environmental variables affect school efficiency. For example, Alexander et al. (2010) and Burney et al. (2013) argued teacher quality and experience had a positive impact on efficiency. Wanke et al. (2016) also found experience had an impact on efficiency as well as attendance and special educational offerings, while Kantabutra and Tang (2006) and Huguenin (2015) suggested that school size also had a role to play. Elsewhere, Lewis et al. (2011) noted funding was important, as did Agasisti (2011) and Misra et al. (2012) for competition, and Rassouli-Currier (2007), Alexander et al. (2010) and Chakraborty and Blackburn (2013) for student socioeconomic background. Bogetoft et al. (2015) found no significance between the length of teacher training and PISA scores with efficiency levels, as did Agasisti (2014) who also found GDP per capita to be negatively correlated with efficiency. Santín and Sicilia (2015) found no significance between reduced class size via recruiting more teachers and efficiency, but argued that promoting teaching and learning techniques enhanced study skills and thereby positively impacted efficiency. Other studies variously included other environmental variables such as private vs. public governance, single-sex vs. co-ed instruction, and geographic location.

However, many of these variables are in no small part meaningless because they do not have any obvious or at least realistic policy implications. For instance, if there is a finding that an all-girls school is more efficient than an all-boys school, what does this suggest for policymakers? The same goes for single-sex and co-ed schools or public and private schools. Moreover, precisely how would a finding that urban schools are more efficient than rural schools influence geographic placement? Such environmental variables serve little practical purpose for management and policymakers in finding ready-to-use ways to improve underperforming schools. It is therefore only meaningful to consider variables in these efficiency studies that are pragmatic and allow for practical policy implementation. 
From the studies in Table 1, along with the literature detailed in Worthington (2001) and De Witte and López-Torres (2017), we noted that one factor not previously considered is the impact teachers have on student performance. This variable is an attribute that demonstrates the quality of the teacher-student relationship and their engagement. While some studies specify quality attributes such as teacher qualification, years of teaching experience, and teaching techniques, they do not generally measure the direct impact of teachers on student learning. This is where the education production process differs most markedly to a mechanical production process. In the latter, inputs are fully consumed to generate outputs, whereas in the former, a student's ability to absorb information via the learning process (i.e. input consumption) may be affected by a large number of competing and corresponding factors. In essence, what most educators would ask is "How should I teach to improve student performance?" and "What can we do to improve student learning?". In fact the answer lies with students. Hence key questions that should really be asked are, "Has the student learned anything?" and "Does the student feel motivated throughout the learning activity?" It is from such questions that educators can then begin to understand what is required in order to raise student performance and efficiency levels.

Hence, the learning process is incomplete, which typically results in subpar performance being measured. This is because the context of education is much more complex as there are sociological and psychological factors that play a significant role in the outcome of student performance. Student surroundings and especially teacher impacts on student performance also affect the academic outcomes of students (Silver et al, 2005; Baker et al., 2008; O'Connor et al., 2011). Unfortunately, while there are data on socioeconomic factors, data on teacher impact on student learning is uncommon. Consideration of this variable would provide management and policymakers with a better understanding of ways to improve student performance and allocate resources more effectively. 
As Hanushek (2003, p. F91) argues: “...school resources are not closely related to student performance" which suggests that there is a need to go beyond conventional easy-to-obtain school inputs and attempt to identify some of the holistic factors that influence student learning, namely teacher-student engagement. As Halkos et al. (2015, p. 703) noted, "[the] opinions of school managers, teachers and parents through a questionnaire would be a useful tool for analysis," which suggests the identification and collection of data on holistic factors. We thus hypothesize that teachers directly affect student learning and performance. To determine the impact teachers have on student performance, we use Queensland state primary schools as a suitable case because data on teacher impact on student learning is readily available via student opinion surveys.

The remainder of the paper is organized as follows. Section 2 presents the methodology. Section 3 describes the data and Section 4 provides the results. Section 5 concludes, including some brief comments on the policy implications.

\section{Methodology}

Data envelopment analysis (DEA), as developed by Charnes et al. (1978) under the assumption of constant returns to scale (CRS) and further extended by Banker et al. (1984) under variable returns to scale (VRS), is a nonparametric method that measures the efficiency of decisionmaking units (DMUs). DEA has proven to be a useful tool for measuring efficiency, as it allows multiple inputs and outputs and these are well suited to education contexts. It also does not require the specification of a specific functional form relating inputs to outputs or the setting of weights for the various factors. DEA thus optimizes for each observation an efficient frontier - the maximum outputs empirically obtainable for any DMU (here schools) in the observed population given its level of inputs. For a general overview of DEA, see Coelli et al. (2005).

We use the Farrell/Debreu-type output-oriented VRS model to derive technical efficiency (TE) scores. We do not consider the CRS assumption as this condition is only appropriate when 
schools are operating at their optimal scale. This is an unlikely situation in the context of education in Queensland because of the continuous implementation of education reforms. Notable examples include the 2007 introduction of Prep (an additional year preceding the existing six years of primary school), the change to the school starting age in 2008 (children commencing school must be five years of age by June of that year), and boosting the performance of schools in $2013 .{ }^{1}$

The assumption of VRS also appears appropriate given that our study focuses on primary schools, which are heterogeneous in terms of facilities, student socioeconomic background, and staff, and with schools located in different regions ranging from large metropolitan cities to regional towns and rural areas. The output-oriented VRS DEA model is expressed as:

$$
\hat{\theta}_{i}=\max _{\hat{\theta}, \lambda}\left\{\theta_{i 0}>0 \mid \hat{\theta}_{i} y_{i} \sum_{i=1}^{n} y_{i} \lambda ; \quad x_{i} \geq \sum_{i=1}^{n} x_{i} \lambda ; \quad \sum_{i=1}^{n} \lambda=1 ; \quad \lambda \geq 0\right\}, \quad i=1, \ldots, n \text { firms }
$$

where $y_{i}$ is a vector of outputs, $x_{i}$ is a vector of inputs, and $\lambda$ is an I x 1 vector of constants. The value obtained for $\hat{\boldsymbol{\theta}}_{\boldsymbol{i}}$ is the TE score for the i-th DMU. A measure of $\hat{\boldsymbol{\theta}}_{\boldsymbol{i}}=\mathbf{1}$ indicates that the DMU is technically efficient, whereas it is inefficient if $\hat{\theta}_{i}>1$. This linear programming problem must be solved $n$ times, once for each DMU (here school) in the sample.

DEA, however, has some limitations. There is no error term in DEA such that mismeasurement and misspecification errors are included in the efficiency estimates. DEA scores also provide no conventional measures of statistical significance owing to its nonparametric nature and so are unable explain to directly the sources of inefficiency. To overcome this problem, Ray (1991) and Coelli et al. (2005) suggested the use of a two-stage analysis, whereby the second stage employs a regression analysis.

By their nature, DEA efficiency scores are bounded at unity from above, thereby making them a limited dependent variable (McDonald, 2009; Ramalho et al., 2010). Econometric modelling

\footnotetext{
${ }^{1}$ See http://flyingstart.qld.gov.au/Pages/home.aspx\#2.
} 
of bounded dependent variables - especially non-binary variables with a significant number of observations at the extremes-becomes a challenge because it makes the application of standard linear models inappropriate. The use of logit and probit models given their strong distributional assumptions for the underlying population provides only a limited approach to solving the problem. Tobit regressions, on the other hand, are appropriate when the dependent variable is limited either above or below, but is unbounded elsewhere (Ramalho et al, 2010).

Simar and Wilson (2007) noted that many of the studies adopting a two-stage approach and regressing DEA scores on covariates (i.e. environmental variables) suffer from the problem of serial correlation. Hence, direct regression analysis is invalid owing to the dependency of the efficiency scores. To overcome this problem, they proposed an alternative estimation and statistical inference procedure based on a double-bootstrap approach. We employ this approach in our analysis. ${ }^{2}$ By combining DEA with bootstrapping techniques, we successfully generate a set of bias-corrected estimates of the DEA efficiency scores (denoted $\hat{\hat{\theta}}_{\boldsymbol{i}}$ ) and confidence intervals that help resolve this problem. In the second stage of our analysis, we regress the bias-corrected efficiency scores derived from the bootstrap algorithm on a set of environmental variables using the following regression model:

$$
\hat{\hat{\theta}}_{i}=a+Z_{i} \delta+\varepsilon_{i}, \quad i=1, \ldots, n
$$

where $\varepsilon_{i} \sim N\left(0, \delta_{\varepsilon}^{2}\right)$ is an error term with left-truncation at $1-Z_{i} \delta, a$ is a constant term and $Z_{i}$ is a vector of specific variables for school $i$ expected to influence school efficiency. Simar and Wilson (2007, 2011) detail the bootstrap truncated regression algorithm, which is also described step-bystep in Alexander et al. (2010). We refer the interested reader to these studies for details.

\footnotetext{
2 Hoff (2007), Simar and Wilson (2007, 2011), McDonald (2009) and Ramalho et al. (2010) review the various models used for explaining efficiency scores using regression analysis.
} 
We use the software package rDEA version 1.2-4 developed by Simm and Besstremyannaya (2016) to carry out the DEA and double-bootstrap estimations. In turn, rDEA is based on the statistical package R Version 3.2.4.

\section{Data}

Our data are from two sources: the Australian Curriculum, Assessment and Reporting Authority (ACARA) and annual school reports. The sample comprises 430 state (public) primary schools drawn from some 920 state primary schools in the Australian state of Queensland. We consider only state schools because the annual reports of independent schools did not provide consistent data for the second-stage analysis. We also included only those schools with more than 10 full-time equivalent (FTE) students enrolled and those that had conducted National Assessment Program - Literacy and Numeracy (NAPLAN) tests for Years 5 and 7. Year 3 was not included in our data as there were no average class sizes available in the school annual reports for the secondstage analysis. Other exclusions include schools that did not publish their 2013 annual report on their school website, schools with dubious data, and schools with fewer than 30 respondents in the school opinion survey. This process helps avoid bias in the second-stage analysis.

The outputs in the first stage are the 2014 NAPLAN scores. NAPLAN, introduced in 2008, is a national annual assessment conducted by ACARA in May each year for students in Years 3, 5, 7 and 9. It is an appealing output measure because it is a qualitative measure and a national assessment that satisfies consistency, with scores being directly comparable between schools, both within Queensland and Australia as a whole. NAPLAN assesses students in four areas: reading, writing, language conventions (i.e. spelling, grammar and punctuation), and numeracy, and reports 
the results using a common national scale range of 0 to 1,000 . Thus, a school with a NAPLAN score of 500 indicates that 500 is the average score across all participating students in that school. ${ }^{3}$

We use two NAPLAN outputs, one for Year 5 and the other for Year $7 .{ }^{4}$ Each output is on the arithmetic mean test scores of reading, writing, spelling, grammar and punctuation, and numeracy. To keep the measurements of input consistent with that of output (i.e. average score), our inputs are per FTE student. Hence, our inputs for the first stage are the ratios of FTE teaching staff per FTE student and cumulative capital expenditure per FTE student. The capital estimates are derived from the cumulative capital expenditures from 2009 to 2013 because we consider this input to have a continuous effect on the progress of student education lifespan leading to the performance of the 2014 NAPLAN scores.

Consequently, to measure the performance of Year 5 students, we require the cumulative capital expenditures of previous years. Ideally, we would have considered the previous seven years (which makes up the duration of primary school education in Queensland) from 2007 to 2013. However, ACARA does not provide capital expenditure estimates for 2007 and 2008, which thus limits our capital expenditure from 2009 to 2013. Furthermore, NAPLAN testing is only in May each year and it would be meaningless to use the 2014 inputs. Hence, to ensure an appropriate production model for NAPLAN 2014 test scores, we therefore rely on the 2009 to 2013 inputs unless otherwise specified.

With regards to the variables in the second-stage analysis, our focus is on determining the sources of (in)efficiency to provide management and policymakers with practical avenues to improve school performance. As argued earlier, it is important to identify pragmatic and meaningful environmental variables that may affect student performance. We identify 16 environmental variables of which four are non-surveyed data and twelve are survey data. The four non-surveyed

\footnotetext{
${ }^{3}$ More details on the assessment process and description on skills and understandings typical of students at various proficiency levels along each scale are available on the NAPLAN website http://www.nap.edu.au.

${ }^{4}$ Note that in 2013, Year 7 was the final year of primary school and hence we do not consider the scores in Year 9.
} 
data are the index of community socio-educational advantage (ICSEA) value, average class size, the ratio of teachers with postgraduate qualifications to bachelors' degrees, and funds spent on professional development in 2013 per FTE teaching staff. The ICSEA variable is from ACARA, whereas the other three variables are from each school's 2013 annual report.

The twelve surveyed data variables are from the student opinion survey available via the Queensland government website (http://education.qld.gov.au/schoolopinionsurvey/). These comprise: (i) know assessment, (ii) use computers, (iii) English development, (iv) Maths development, (v) students' opinions, (vi) schoolwork challenging, (vii) teachers challenge, (viii) teachers explain, (ix) teachers help, (x) teachers motivate, (xi) feedback, and (xii) variety of resources. The Queensland Department of Education and Training administers the student survey opinion annually and obtains opinions from parents/caregivers, students, staff and principals. Opinions are based on a 6-point response scale ranging from strongly disagree to strongly agree.

ICSEA, developed by ACARA, is a scale of socio-educational advantage of each school based on the characteristics of the family and school including parental education and occupation and school characteristics such as location and socio-economic background of the students. We hypothesize that the socio-economic background of the students' family influences the educational performance of students, that is, student scores. Class size can have a profound impact on a student's results according to Zyngier (2014, p.14) because small classes offer more “...more individualized teacher support for learning.” As Greenwald et al. (1996), Nye et al. (2000), Blatchford et al. (2003), and Burke and Sass (2013) argue, reducing class size to the ideal class size improves student performance. Postvgrad is hypothesized that the greater the ratio (i.e. more teachers with postgraduate qualification), the better the student scores. Development refers to funds spent on professional development, which fosters teacher and curriculum development and assumed to improve student scores. 
Know assessment refers to students understanding how they are assessed which suggests the more familiar with assessment curriculum, the better prepared the student is. Use computers refers to students who use computers and technology at school, which supposedly enhances their learning outcome. OECD (2015) noted that frequent use of computers had no noticeable improvement in the Programme for International Student Assessment (PISA) results, with Australia having the highest average minutes in internet usage and top in the smallest number of students per school computer at 0.9. OECD (2015) also observed that the moderate use of computers by schools such as those in Singapore came in top in digital skills. English and Maths refers to students' perceptions that school develops English and Maths skills, respectively. This suggest a direct relationship between student's opinion and NAPLAN numeracy scores thus raising school performance. Opinion refers to schools taking students' opinions seriously, while Schoolwork is a reflection of when schoolwork challenges students to think. This suggests that students develop their thinking process through more challenging schoolwork due to clear setting of challenging learning intentions, which can raise student performance, as noted in Hattie (2009).

\section{$<$ INSERT TABLE II HERE $>$}

Challenge refers to teachers challenging students to think, suggesting that the development of critical thinking skills can positively influence student performance. Explain refers to teachers clearly explaining what is required in student's schoolwork suggests that clear explanation of the schoolwork makes it easier for students to address the task at hand. Help refers to teachers helping students in their schoolwork when needed. Motivate refers to students who believe that teachers motivate students to learn. The implication of this is that a students' perception that a teacher is demonstrating motivation would lead them to become motivated to learn which results in better scores. Feedback refers to teachers providing useful feedback in students schoolwork suggests 
formative feedback can improve student learning. Hattie (2009) noted that evidence from numerous studies showed that feedback is essential to student performance. Variety refers to the teachers using a variety of resources to help student learning. Table 2 presents descriptive statistics of the inputs, outputs, and environmental variables.

\section{Results}

The DEA model identified 13 schools as efficient, namely Ashgrove, Buranda, Eumundi, Federal, Forest Hill, Greenlands, Indooroopilly, Ironside, MacGregor, Maleny, Rainworth, Samford and Sunnybank Hills, closely followed by several schools with a TE of 0.99, namely Fig Tree Pocket, Kenmore South, Seven Hills, Chapel Hill and Graceville. The average TE score was 1.157 and ranged between 1.000 and 1.420. Spearman rank correlation of TE scores with respect to the performance of Years 5 and 7 scores were 0.837 and 0.859 , respectively. This high correlation is evident form scatter plot in Figure 1 whereby the more efficient the school, the higher the NAPLAN scores. We also observed that the NAPLAN scores for Year 7 were higher than for Year 5, which also suggests an improvement in student performance over time, although we would like to point out that these are two separate cohorts of students.

\section{$<$ INSERT FIGURE 1 HERE $>$}

\subsection{Determinants of efficiency}

We quantify the determinants of efficiency using Simar and Wilson's (2007) double bootstrap truncated regression based on the maximum likelihood estimation. The estimated specification for the regression is:

$\hat{\hat{\theta}}_{i}=\beta_{0}+\beta_{1} I C S E A+\beta_{2}$ class_size $+\beta_{3}$ postvgrad $+\beta_{4}$ development $+\beta_{5} k n o w \_$assessment 


\section{$+\beta_{6} u s e \_c o m p u t e r s+\beta_{7}$ english $+\beta_{8}$ maths $+\beta_{9}$ opinion $+\beta_{10}$ schoolwork $+\beta_{11}$ challenge \\ $+\beta_{12}$ explain $+\beta_{13}$ help $+\beta_{14}$ motivate $+\beta_{15}$ feedback $+\beta_{16}$ variety}

where $\hat{\hat{\theta}}_{i}$ is the bootstrapped bias-corrected efficiency score.

Table 3 provides the estimated coefficients and 95 percent confidence intervals for the second stage estimation. As our model employs an output-orientation, whereby efficiency scores range from one to infinity, a positive sign for a coefficient indicates a negative influence on efficiency, whereas a negative sign indicates a positive influence on efficiency.

\section{$<$ INSERT TABLE III HERE $>$}

We can see that ICSEA, Opinion and Explain are statistically significantly and positively influences efficiency. ICSEA, which provides the socio-educational and economic characteristics of family and school, suggests that students of families with better socio-educational economic background in a school with ideal facilities perform better. This finding is consistent with other studies such as Rassouli-Currier (2007), Alexander et al. (2010), and Chakraborty and Blackburn (2013). Concerning Opinion, the results suggest that students perform better and achieve better scores because they believe their school takes student's opinion seriously. This suggests the consideration and discussion of students' views in class. This a sign that a school is receptive to student opinion thus positively affecting student's perception of teachers and their performance.

Explain also impacts positively on student performance demonstrates the importance of effective communication towards student learning and outcome. When teachers clearly explain what is required in the schoolwork, it clarifies the issue and helps student understand the requirements to complete a schoolwork task. Variety is statistically significant and negatively affects efficiency, which suggests that excessive use of a variety of resources negatively affects student learning. This 
may be an indication of diminishing returns whereby excessive use of technology can reduce the impact of student learning.

Our study also observed some interesting findings on some of the insignificant variables. Postvgrad is statistically insignificant but its negative impact on efficiency would suggest that some schools might be underutilizing the skills and knowledge of postgraduate teachers. Class size has a negative coefficient but is statistically insignificant which is consistent with Agasisti and Bonomi (2014) and Santín and Sicilia (2015) but not so with Kantabutra and Tang (2006) which found class size to have a positive effect on urban schools and a negative impact on rural schools. Hence, there is insufficient evidence to support the claim that students perform better when the number of students per class falls to the desired number. Use computers has a negative impact on efficiency, which would suggest diminishing returns from excess use of computers. As noted, Australian schools are the most enthusiastic users of computers in schools in the OECD. Challenge has a negative impact on efficiency would suggest that teachers challenging students to think may not be effective for a myriad of reasons ranging from students lack of motivation to not understanding the question at hand. Motivation is insignificant but seems to indicate that students perform better and achieve better scores because they become motivated through teachers motivation.

\section{Conclusion}

This study employed DEA to derive efficiency scores and the double bootstrap truncated regression of Simar and Wilson (2007) to quantify the sources of efficiency in 430 Queensland state primary schools. The focus of the study was to ascertain whether teacher motivation affects student learning and consequently student performance. By considering the impact of practical environmental variables, our results show that socio-economic background, student opinion, and teacher's clear explanation positively affects school efficiency. From a policy perspective, the results suggest that policymakers can direct resources in providing resources to underperforming schools 
aimed at enhancing student learning through teacher development and at the same time providing financial and non-financial educational assistance to families of lesser socio-educational background. However, Alexander et al, (2010) had reservations regarding more funding for inefficient schools affected by low socio-economic background because reducing funding could simply raise the efficiency levels of the school, assuming that the school already has low output values or high input values. Hence, funding would be better served if directed at areas where there are long-term returns, namely investing in teacher development.

Although not all variables related to teachers' contribution are significant, there is still sufficient evidence to suggest that this study confirms teachers have a positive influence on student performance hence school efficiency. Teachers ability to clearly explain the requirements of schoolwork tasks and listening to student opinions sets an ideal student engagement environment which can have a profound impact on student learning. Likewise, the opposite effect could influence student performance if teachers do not engage sufficiently and effectively in student learning. That said, teacher contribution and commitment also needs recognition. For example, Kittel and Leynen (2003) noted that limited personal accomplishment and loss of meaningfulness in teachers' work could have a negative impact on teacher's performance. Kleinhenz and Ingvarson (2004) argued that micro-management and strict regulations reduces motivation, self-esteem and performance which impacts on student performance. From a policy perspective, it is important to recognize the contribution of teachers via awards, provide sufficient and appropriate support; and outline clear guidelines and objectives when national policies change in order to sustain their motivation.

\section{References}

Agasisti, T. (2011), "How competition affects schools' performances: Does specification matter?", Economics Letters, Vol. 110, No. 3, pp. 259-261.

Agasisti, T. (2014), "The efficiency of public spending on education: An empirical comparison of EU countries", European Journal of Education, Vol. 49 No. 4, pp. 543-557.

Agasisti, T., and Bonomi, F. (2014), "Measuring the "managerial" efficiency of public schools: A case study in Italy", International Journal of Educational Management, Vol. 28 No. 2, pp. 
$120-140$.

Alexander, W.R.J., Haug, A.A. and Jaforullah, M. (2010), "A two-stage double-bootstrap data envelopment analysis of efficiency differences of New Zealand secondary schools", Journal of Productivity Analysis, Vol. 34 No. 1, pp. 99-110.

Baker, J., Grant, S. and Morlock, L. (2008), “The teacher-student relationship as a developmental context for children with internalizing or externalizing behaviour problems", School Psychology Quarterly, Vol. 23 No. 1, pp. 3-15.

Banker, R.D., Charnes, A. and Cooper, W. (1984), "Some models for the estimation of technical and scale efficiencies in data envelopment analysis", Management Science, Vol. 30 No. 9, pp. $1078-1092$.

Blackburn, V., Brennan, S. and Ruggiero, J. (2014), "Measuring efficiency in Australian schools: A preliminary analysis”, Socio-Economic Planning Sciences, Vol. 48 No. 1, pp. 4-9.

Blatchford, P., Bassett, P., Goldstein, H. and Martin, C. (2003), "Are class size differences related to pupils' educational progress and classroom processes? Findings from the institute of education class size study of children aged 5-7 years", British Educational Research Journal, Vol. 29 No. 5, pp. 709-730.

Bogetoft, P., Heinesen, E. and Tranæs, T. (2015), "The efficiency of educational production: A comparison of the Nordic countries with other OECD countries", Economic Modelling, Vol. 50, pp. 310-321.

Burke, M.A. and Sass, T.R. (2013), "Classroom peer effects and student achievement”, Journal of Labor Economics, Vol. 31 No. 1, pp. 51-82.

Burney, N.A., Johnes, J., Al-Enezi, M. and Al-Musallam, M. (2013), "The efficiency of public schools: The case of Kuwait", Education Economics, Vol. 21 No. 4, pp. 360-379.

Chakraborty, K. and Blackburn, V.C. (2013), "Efficiency and equity in funding for government schools in Australia", Australian Economic Papers, Vol. 52 No. 3-4, pp. 127-142.

Charnes, A., Cooper, W.W. and Rhodes, E. (1978), "Measuring the efficiency of decision-making units", European Journal of Operations Research, Vol. 2, pp. 429-444.

Coelli, T., Rao, D.S.P., O’Donnell, C.J. and Battese, G.E. (2005). An Introduction to Efficiency and Productivity Analysis, 4th ed., New York, Springer.

Conroy, S.J. and Arguea, N.M. (2008), "An estimation of technical efficiency for Florida public elementary schools", Economics of Education Review, Vol. 27 No. 6, pp. 655-663.

Cordero-Ferrera, J.M., Pedraja-Chaparro, F. and Salinas-Jiménez, J. (2008), Measuring efficiency in education: An analysis of different approaches for incorporating non-discretionary inputs", Applied Economics, Vol. 40 No. 10, pp. 1323-1339.

Cordero, J.M., Santín, D. and Simancas, R. (2017), “Assessing European primary school performance through a conditional nonparametric model", Journal of the Operational Research Society, Vol. 68 No. 4, pp. 364-376.

De Witte, K. and López-Torres, L. (2017), "Efficiency in education: A review of literature and a way forward", Journal of the Operational Research Society, Vol. 68 No. 4, pp. 339-363.

Greenwald, R., Hedges, L.V. and Laine, R. (1996), "The effect of school resources on student achievement", Review of Educational Research, Vol. 66 No. 3, pp. 361-396.

Grosskopf, S., Hayes, K.J. and Taylor, L.L. (2014), "Efficiency in education: Research and 
implications", Applied Economic Perspectives and Policy, Vol. 36 No. 2, pp. 175-210.

Haelermans, C. and Ruggiero, J. (2013), "Estimating technical and allocative efficiency in the public sector: A nonparametric analysis of Dutch schools", European Journal of Operational Research, Vol. 227 No. 1, pp. 174-181.

Haelermans, C., De Witte, K. and Blank, J.L.T. (2012), "On the allocation of resources for secondary schools", Economics of Education Review, Vol. 31 No. 5, pp. 575-586.

Halkos, G.E., Tzeremes, N.G. and Kourtzidis, S.A. (2015), "Weight assurance region in two-stage additive efficiency decomposition DEA model: An application to school data", Journal of the Operational Research Society, Vol. 66 No. 4, pp. 696-704.

Hanushek, E.A. (2003), "The failure of input-based schooling policies”, The Economic Journal, Vol. 113 No. 1, pp. F64-F98.

Hattie, J. (2009), Visible Learning: A Synthesis of Over 800 Meta-Analyses Relating to Achievement, Routledge, Abingdon.

Hoff, A. (2007), "Second stage DEA: Comparison of approaches for modelling the DEA score", European Journal of Operational Research, Vol. 181 No. 1, pp. 425-435.

Huguenin, J-M. (2015), "Determinants of school efficiency", International Journal of Educational Management, Vol. 29 No. 5, pp. 539-562.

Kantabutra, S. and Tang, J.C.S. (2006), "Urban-rural and size effects on school efficiency: The case of Northern Thailand", Leadership and Policy in Schools, Vol. 5 No. 4, pp. 355-377.

Kittel, F. and Leynen, F. (2003), "A study of work stressors and wellness/health outcomes among Belgian school teachers", Psychology and Health, Vol. 18 No. 4, pp. 501-510.

Kleinhenz, E. and Ingvarson, L. (2004), "Teacher accountability in Australia: Current policies and practices and their relation to the improvement of teaching and learning", Research Papers in Education, Vol. 19 No. 1, pp. 31-49.

Lewis, B.D., Pattinasarany, D. and Sahn, D.E. (2011), "The cost of public primary education in Indonesia: Do schools need more money?", Education Economics, Vol. 19 No. 4, pp. 397 410.

McDonald, J. (2009), "Using least squares and Tobit in second stage DEA efficiency analyses", European Journal of Operational Research, Vol. 197 No. 2, pp. 792-798.

Misra, K., Grimes, P.W. and Rogers, K.E. (2012), "Does competition improve public school efficiency? A spatial analysis", Economics of Education Review, Vol. 31 No. 6, pp. 1177 1190.

Nye, B., Hedges, L.V. and Konstantopoulos, S. (2000), "The effects of small classes on academic achievement: The results of the Tennessee class size experiment", American Educational Research Journal, Vol. 37 No. 1, pp. 123-151.

O'Connor, E.E., Dearing, E. and Collins, B.A. (2011), “Teacher-child relationship and behaviour problem trajectories in elementary school", American Educational Research Journal, Vol. 48 No. 1, pp. 120-162.

OECD (2015). Students, Computers and Learning: Making the Connection, OECD Publishing, Paris.

Podinovski, V.V., Ismail, I., Bouzdine-Chameeva. and Zhang, W. (2014), "Combining the assumptions of variable and constant returns to scale in the efficiency evaluation of secondary 
schools”, European Journal of Operational Research, Vol. 239 No. 2, pp. 504-513.

Ramalho, E.A., Ramalho, J.J. and Henriques, P.D. (2010), "Fractional regression models for second stage DEA efficiency analyses”, Journal of Productivity Analysis, Vol. 34 No. 3, pp. 239-255.

Rassouli-Currier, S. (2007), "Assessing the efficiency of Oklahoma public schools: A data envelopment analysis", Southwestern Economic Review, Vol. 34 No. 1, pp. 131-144.

Ray, S.C. (1991), "Resource-use efficiency in public schools: A study of Connecticut data", Management Science, Vol. 37 No. 12, pp. 1620-1628.

Santín, D. and Sicilia, G. (2015), "Measuring the efficiency of public schools in Uruguay: Main drivers and policy implications", Latin American Economic Review, Vol. 24 No. 5, pp. 1-28.

Silver, R.B., Measelle, J.R., Armstrong, J.M. and Essex, M.J. (2005), “Trajectories of classroom externalizing behaviour: Contributions of child characteristics, family characteristics, and the teacher-child relationship during the school transition", Journal of School Psychology, Vol. 43 No. 1, pp. 39-60.

Simar, L. and Wilson, P.W. (2007), "Estimation and inference in two-stage, semi-parametric models of production processes", Journal of Econometrics, Vol. 136 No. 1, pp. 31-64.

Simar, L. and Wilson, P.W. (2011), "Two-stage DEA: Caveat emptor", Journal of Productivity Analysis, Vol. 36 No. 2, pp. 205-218.

Simm, J. and Besstremyannaya, G. (2016), Robust Data Envelopment Analysis for R. Version 1.24, available at: https://cran.r-project.org/web/packages/rDEA/rDEA.pdf (accessed 3 November 2017.

Wanke, P., Blackburn, V. and Barros, C.P. (2016), Cost and learning efficiency drivers in Australian schools: A two-stage network DEA approach", Applied Economics, Vol. 48 No. 38, pp. 3577 3604 .

Worthington, A. (2001), "An empirical survey of frontier efficiency measurement techniques in education", Education Economics, Vol. 9 No. 3, pp. 245-268.

Zyngier, D. (2014), "Class size and academic results, with a focus on children from culturally, linguistically and economically disenfranchised communities", Evidence Base, Vol. 1 No. 1, pp. 1-23. 
Table I.

Selected frontier efficiency studies in primary and/or secondary education

\begin{tabular}{|c|c|c|c|c|c|}
\hline Author(s) & Methodology & Sample & Inputs, outputs, explanatory variables (if applicable) & Analytical technique & Main findings \\
\hline $\begin{array}{l}\text { Cordero et al. } \\
\text { (2017) }\end{array}$ & $\begin{array}{l}\text { Robust and } \\
\text { conditional } \\
\text { FDH model }\end{array}$ & $\begin{array}{l}2,398 \text { Primary } \\
\text { schools } \\
\text { across } 16 \\
\text { European } \\
\text { countries, } \\
2011\end{array}$ & $\begin{array}{l}\text { Inputs: Number of teachers per a hundred students; instruction hours per week; } \\
\text { number of computers per a hundred students; socioeconomic status of pupils } \\
\text { (index). } \\
\text { Outputs: Average results in reading. } \\
\text { Contextual variables: early literacy skills of students before entering the primary } \\
\text { grades; average level of classroom disciplinary climate; the parental involvement } \\
\text { at home; the parental involvement in school; problem of absenteeism at the } \\
\text { school; whether the school is placed in a rural area; GDP per capita; public } \\
\text { expenditure per student (\% of GDP per capita); hard work, responsibility and } \\
\text { perseverance. }\end{array}$ & $\begin{array}{l}\text { Descriptive analysis, } \\
\text { local linear least } \\
\text { squares regression } \\
\text { analysis, nonparametric } \\
\text { regression significance } \\
\text { test, bootstrap tests. }\end{array}$ & $\begin{array}{l}\text { Results indicate that } \\
\text { heterogeneity across } \\
\text { countries is more relevant } \\
\text { than among schools. }\end{array}$ \\
\hline $\begin{array}{l}\text { Wanke et al. } \\
\text { (2016) }\end{array}$ & Network DEA & $\begin{array}{l}\text { NSW primary } \\
\text { and secondary } \\
\text { public } \\
\text { schools, } 2008- \\
\quad 2010\end{array}$ & $\begin{array}{l}\text { Inputs: Total expenses; teacher salaries; school administrative and support staff } \\
\text { salaries; depreciation expense; maintenance expenses; insurance expenses; } \\
\text { cleaning expenses; other salaries; subtotal of other expenses; school land value; } \\
\text { school buildings written down value; value of land and buildings combined; } \\
\text { 'school own source' expenditure; other operating expenses by student. } \\
\text { Intermediates: Teachers (FTE); school administrative and support staff (FTE); } \\
\text { students; female students; teachers plus school administrative and support staff } \\
\text { (FTE); male students. } \\
\text { Outputs: NAPLAN Reading test score, writing test score, spelling test score, } \\
\text { grammar test score, numeracy test score and average test score for years 3, 5, } 7 \\
\text { and 9; ICSEA. } \\
\text { Contextual variables: school location (provincial, metropolitan, remoteness, etc.); } \\
\text { extra-curricular emphasis or schooling focus (agricultural technology, selective, } \\
\text { only boys, only girls, etc.); basic productivity indicators (average salaries, etc.); } \\
\text { teacher profile (years of experience, etc.). }\end{array}$ & $\begin{array}{l}\text { Descriptive analysis, } \\
\text { principal component } \\
\text { analysis }\end{array}$ & $\begin{array}{l}\text { Findings indicate that there } \\
\text { is an ambiguous impact of } \\
\text { different contextual variables } \\
\text { on efficiency levels within } \\
\text { the context of primary and } \\
\text { secondary schools. But it is } \\
\text { recognized that experienced } \\
\text { teachers and school location } \\
\text { appear to be the most } \\
\text { comprehensive and relevant } \\
\text { drivers for cost and learning } \\
\text { efficiency. }\end{array}$ \\
\hline $\begin{array}{l}\text { Bogetoft et al. } \\
\text { (2015) }\end{array}$ & DEA & $\begin{array}{l}\text { Schools in } \\
\text { Nordic and } \\
\text { OECD } \\
\text { countries, } \\
2010\end{array}$ & $\begin{array}{l}\text { Inputs: Total expenditure. } \\
\text { Outputs: (Model 1) Number of students; (Model 2) Graduation rates; (Model 3) } \\
\text { Completion rates; (Model 4) Expected earnings. } \\
\text { Second-stage variables: length of teacher training for various educational levels; } \\
\text { students' PISA scores; per capita GDP. }\end{array}$ & $\begin{array}{l}\text { Descriptive analysis, } \\
\text { second-stage Tobit } \\
\text { regression (DEA). }\end{array}$ & $\begin{array}{l}\text { Policy implications: large } \\
\text { savings potentials in } \\
\text { Denmark and Norway. } \\
\text { Results should be interpreted } \\
\text { cautiously as they are } \\
\text { dependent on specification. }\end{array}$ \\
\hline
\end{tabular}




\begin{tabular}{|c|c|c|c|c|c|}
\hline Author(s) & Methodology & Sample & Inputs, outputs, explanatory variables (if applicable) & Analytical technique & Main findings \\
\hline $\begin{array}{l}\text { Halkos et al. } \\
\text { (2015) }\end{array}$ & DEA & $\begin{array}{c}\text { Secondary } \\
\text { schools across } \\
65 \text { countries, } \\
2009\end{array}$ & $\begin{array}{l}\text { Inputs: Level of students' agreement with five statements about the teacher- } \\
\text { student relationship } \\
\text { Intermediates: Level of students' disagreement with five statements of } \\
\text { disciplinary climate. } \\
\text { Outputs: PISA test scores in reading; PISA test scores in mathematics; PISA test } \\
\text { scores in science. }\end{array}$ & $\begin{array}{l}\text { Descriptive analysis, } \\
\text { Spearman rank } \\
\text { correlation. }\end{array}$ & $\begin{array}{l}\text { Results suggest that } \\
\text { restrictions should be used } \\
\text { with caution. Opinions of } \\
\text { school managers, teachers } \\
\text { and parents through a } \\
\text { questionnaire would be a } \\
\text { useful tool for analysis. }\end{array}$ \\
\hline $\begin{array}{l}\text { Huguenin } \\
(2015)\end{array}$ & DEA & $\begin{array}{l}90 \text { State of } \\
\text { Geneva } \\
\text { (Swiss) } \\
\text { schools, } \\
2010 / 11\end{array}$ & $\begin{array}{l}\text { Inputs: Number of full-time equivalent teaching staff per pupil; number of full- } \\
\text { time equivalent administrative and technical staff per pupil; and school budget in } \\
\text { Swiss francs per pupil (excludes staff salaries and capital expenditure). } \\
\text { Outputs: Results in French and mathematics standardized tests at the end of the } \\
\text { second grade per pupil; results in French, German and mathematics standardized } \\
\text { tests at the end of the fourth grade per pupil; and results in French, German and } \\
\text { mathematics standardized tests at the end of the sixth grade per pupil. } \\
\text { Second-stage variables: Site; special education for special needs; reception } \\
\text { classes for immigrant pupils; urban or rural; number of classes; number of pupils; } \\
\text { percentage of pupils whose parents are blue-collar workers or unqualified } \\
\text { workers; and percentage of allophone pupils. }\end{array}$ & $\begin{array}{l}\text { Descriptive analysis, } \\
\text { Pearson correlation, } \\
\text { Spearman's rank } \\
\text { correlation and ordinary } \\
\text { least squares } \\
\text { regressions analysis }\end{array}$ & $\begin{array}{l}\text { Findings show multi-site } \\
\text { schools, proportion of } \\
\text { disadvantaged pupils and } \\
\text { provision of special } \\
\text { education negatively impacts } \\
\text { on efficiency, whereas } \\
\text { school size is associated with } \\
\text { higher efficiency. }\end{array}$ \\
\hline $\begin{array}{l}\text { Santín and } \\
\text { Sicilia (2015) }\end{array}$ & DEA & $\begin{array}{c}169 \text { public } \\
\text { high schools } \\
\text { in Uruguay, } \\
2009 \text { and } 2012\end{array}$ & $\begin{array}{l}\text { Inputs: students (raw material); teachers (human capital); infrastructure (physical } \\
\text { capital). } \\
\text { Outputs: PISA test scores in reading; PISA test scores in mathematics. } \\
\text { Second-stage variables: Test; homework; percentage of students who spend } \\
\text { between one and } 2 \mathrm{~h} \text { per day reading after school; percentage of students who } \\
\text { check to see if work is remembered; percentage of students who attempt to work } \\
\text { out important parts; PISA period or not; percentage of students assessed in the } \\
\text { school who are in the academic year that a } 15 \text {-year student should really be in; } \\
\text { vocational technical school; rural; city; number of teachers per hundred students } \\
\text { (class size); national authorities have a considerable responsibility for } \\
\text { determining the content of the courses; national authorities have a considerable } \\
\text { responsibility for establishing student disciplinary policies; school principal has a } \\
\text { considerable responsibility for distributing the school budget; national authorities } \\
\text { have a considerable responsibility for distributing the school budget; national } \\
\text { authorities have a considerable responsibility for establishing student assessment } \\
\text { policies. }\end{array}$ & $\begin{array}{l}\text { Descriptive analysis } \\
\text { and second-stage } \\
\text { bootstrap regression } \\
\text { analysis, Tobit } \\
\text { regression, OLS with } \\
\text { bootstrapping. }\end{array}$ & $\begin{array}{l}\text { Increasing educational } \\
\text { resources does not appear to } \\
\text { be an appropriate policy. } \\
\text { Students at risk of repetition } \\
\text { should be identified at an } \\
\text { early age and provided with } \\
\text { extra support with the aim of } \\
\text { preventing future school } \\
\text { failure. Promoting teaching } \\
\text { and learning techniques to } \\
\text { enhance students' study } \\
\text { skills evidences positive } \\
\text { effects on results. }\end{array}$ \\
\hline
\end{tabular}




\begin{tabular}{|c|c|c|c|c|c|}
\hline Author(s) & Methodology & Sample & Inputs, outputs, explanatory variables (if applicable) & Analytical technique & Main findings \\
\hline $\begin{array}{l}\text { Agasisti } \\
(2014)\end{array}$ & $\begin{array}{l}\text { DEA and } \\
\text { Malmquist }\end{array}$ & $\begin{array}{l}20 \text { European } \\
\text { countries, } \\
2006-2009\end{array}$ & $\begin{array}{l}\text { Inputs: Expenditure per student; student-teacher ratio. } \\
\text { Outputs: Math and Science OECD-PISA test scores. } \\
\text { Second-stage variables: GDP per capita; average teachers' salary; proportion of } \\
\text { students who have regular access to the internet at school and at home; } \\
\text { proportion of public spending; instructional time. }\end{array}$ & $\begin{array}{l}\text { Descriptive analysis } \\
\text { and second-stage OLS } \\
\text { regression analysis. }\end{array}$ & $\begin{array}{l}\text { No linear relationship } \\
\text { between expenditures } \\
\text { and educational } \\
\text { performance. National } \\
\text { governments and } \\
\text { supranational authorities } \\
\text { (e.g. the EU) have a role in } \\
\text { promoting initiatives to } \\
\text { foster human capital. }\end{array}$ \\
\hline $\begin{array}{l}\text { Agasisti and } \\
\text { Bonomi, } \\
\text { (2014) }\end{array}$ & DEA & $\begin{array}{c}1062 \text { Italian } \\
\text { Schools, } 2010\end{array}$ & $\begin{array}{l}\text { Inputs: Student-teacher ratio as a proxy for resource intensity; expenditure per } \\
\text { student. } \\
\text { Outputs: Scores in mathematics and literacy/reading used alternatively } \\
\text { Second-stage variables: students' average socio-economic background; school size } \\
\text { by student numbers; average number of students per class; proportion of girls; } \\
\text { proportion of immigrant students; proportion of disabled students; proportion of } \\
\text { students who failed to reach the appropriate standard in previous years, and who } \\
\text { had to repeat one or more years; proportion of teachers who are untenured, and are } \\
\text { employed for one year only; location of the school within the metropolitan area. }\end{array}$ & $\begin{array}{l}\text { Descriptive analysis } \\
\text { and second-stage } \\
\text { bootstrap regression } \\
\text { analysis. }\end{array}$ & $\begin{array}{l}\text { When evaluating managerial } \\
\text { efficiency properly, it is } \\
\text { necessary to use adjusted } \\
\text { efficiency scores to capture } \\
\text { the marginal impacts of } \\
\text { external (out-of-control) } \\
\text { variables. }\end{array}$ \\
\hline $\begin{array}{l}\text { Blackburn et } \\
\text { al (2014) }\end{array}$ & DEA & $\begin{array}{l}1,415 \text { NSW } \\
\text { primary } \\
\text { schools and } \\
381 \text { secondary } \\
\text { schools, } 2010\end{array}$ & $\begin{array}{l}\text { Inputs: Total expenditure per student; Family Occupation Employment and } \\
\text { Income (FOEI) index. } \\
\text { Outputs: NAPLAN test scores. }\end{array}$ & Descriptive analysis & $\begin{array}{l}\text { Primary (secondary) } \\
\text { schools are observed to be } \\
\text { spending about } 23(20) \\
\text { percent above minimum } \\
\text { cost. }\end{array}$ \\
\hline $\begin{array}{l}\text { Grosskopf et } \\
\text { al, (2014) }\end{array}$ & $\begin{array}{l}\text { Cost } \\
\text { efficiency } \\
\text { (SFA, C-OLS } \\
\text { and DEA) }\end{array}$ & $\begin{array}{l}965 \text { Texan } \\
\text { schools, } \\
2010 / 11\end{array}$ & $\begin{array}{l}\text { Inputs: Personnel expenditures per pupil; non-personnel expenditures per pupil; } \\
\text { current operating expenditures per pupil } \\
\text { Prices: Labour cost based on hedonic wage model; price of non-personnel } \\
\text { assumed constant. } \\
\text { Outputs: Percentage of students passing Texas Assessment of Knowledge and } \\
\text { Skills; and normalized gain score indicator. } \\
\text { Environmental variables: Log of school district enrolment; percentage of students } \\
\text { in each district who were not limited English proficient; percentage of students in } \\
\text { each district who were not special education; and percentage of students in each } \\
\text { district who were not economically disadvantaged. }\end{array}$ & $\begin{array}{l}\text { Descriptive analysis, } \\
\text { Spearman rank } \\
\text { correlation, Pearson } \\
\text { correlation }\end{array}$ & $\begin{array}{l}\text { Findings are sensitive to the } \\
\text { type of model used. A mixed } \\
\text { methods approach that } \\
\text { explores the sensitivity of } \\
\text { results is preferred for } \\
\text { effective educational } \\
\text { reforms. }\end{array}$ \\
\hline
\end{tabular}




\begin{tabular}{|c|c|c|c|c|c|}
\hline Author(s) & Methodology & Sample & Inputs, outputs, explanatory variables (if applicable) & Analytical technique & Main findings \\
\hline $\begin{array}{l}\text { Podinovski et } \\
\text { al (2014) }\end{array}$ & $\begin{array}{l}\text { DEA and } \\
\text { Malmquist }\end{array}$ & $\begin{array}{l}221 \text { Malaysian } \\
\text { secondary } \\
\text { schools, } 2005 \\
-2008\end{array}$ & $\begin{array}{l}\text { Inputs: Number of math classes; number of science classes; number of physics } \\
\text { classes; number of biology classes; number of chemistry classes; number of good } \\
\text { math students on entry; number of good science students on entry; number of } \\
\text { Students from the high SES group. } \\
\text { Outputs: Number of students on exit in math; number of students on exit in science; } \\
\text { number of students on exit in physics; Number of students on exit in biology; } \\
\text { number of students on exit in chemistry; number of students achieving good grades } \\
\text { in math; number of students achieving good grades in science; number of students } \\
\text { achieving good grades in physics; number of students achieving good grades in } \\
\text { biology; number of students achieving good grades in chemistry. }\end{array}$ & Descriptive analysis. & $\begin{array}{l}\text { HRS model discriminated } \\
\text { better on the efficiency } \\
\text { scores than conventional } \\
\text { VRS model. }\end{array}$ \\
\hline $\begin{array}{l}\text { Burney et al, } \\
\text { (2013) }\end{array}$ & DEA & $\begin{array}{l}\text { Between } 114 \\
\text { and } 203 \\
\text { Kuwaiti } \\
\text { schools, } \\
1999 / 00 \text { and } \\
2004 / 05\end{array}$ & $\begin{array}{l}\text { Inputs: Teachers; admin staff; number of classrooms. } \\
\text { Outputs: Student numbers. } \\
\text { Second-stage variables: Geographical location; teacher salary; proportion of } \\
\text { teachers who are Kuwaiti nationals and Boys school. }\end{array}$ & $\begin{array}{l}\text { Descriptive analysis, } \\
\text { Spearman's rank } \\
\text { correlation and ordinary } \\
\text { least squares } \\
\text { regressions analysis }\end{array}$ & $\begin{array}{l}\text { Results suggest that teacher } \\
\text { experience and } \\
\text { qualifications influences } \\
\text { efficiency }\end{array}$ \\
\hline $\begin{array}{l}\text { Chakraborty } \\
\text { and } \\
\text { Blackburn } \\
(2013)\end{array}$ & $\begin{array}{l}\text { Cost- } \\
\text { efficiency for } \\
\text { DEA and SFA }\end{array}$ & $\begin{array}{l}3,678 \text { (primary) } \\
\text { and } 1,113 \\
\text { (secondary) } \\
\text { NSW schools, } \\
\text { 2008-2010 }\end{array}$ & $\begin{array}{l}\text { Inputs: student-teacher ratio; student-support staff ratio; average salary for } \\
\text { teachers; average salary for support staff; full time equivalent (FTE) student } \\
\text { enrolment; total expenditure per student; and student enrolment. } \\
\text { Outputs: Year } 10 \text { School Certificate exam results and Year } 12 \text { Higher School } \\
\text { Certificate exam University entrance ATAR results. } \\
\text { Second-stage variables: English as a second language; Aboriginal students; } \\
\text { special education students and parental socio-economic index. }\end{array}$ & $\begin{array}{l}\text { Descriptive analysis, } \\
\text { second-stage Tobit } \\
\text { regression (DEA) and } \\
\text { maximum likelihood } \\
\text { (SFA) }\end{array}$ & $\begin{array}{l}\text { Most cost efficient schools } \\
\text { have lower operating } \\
\text { expenditure per student and } \\
\text { have high enrolments. } \\
\text { Unfavourable environmental } \\
\text { conditions lower efficiency. }\end{array}$ \\
\hline $\begin{array}{l}\text { Haelermans } \\
\text { and Ruggiero } \\
(2013)\end{array}$ & $\begin{array}{l}\text { Cost } \\
\text { efficiency } \\
\text { (DEA) }\end{array}$ & $\begin{array}{l}448 \text { Dutch } \\
\text { schools, } \\
2007 / 08\end{array}$ & $\begin{array}{l}\text { Inputs: management personnel; teaching personnel; supporting personnel and } \\
\text { material expenses. } \\
\text { Prices: Average management price; Average teacher price and Average support } \\
\text { personnel price. } \\
\text { Outputs: the average student national examination grades per school; the average } \\
\text { student achievement each year during secondary education and the total number } \\
\text { of students. } \\
\text { Environmental variables: share of students from a disadvantaged neighborhood. }\end{array}$ & Descriptive analysis & $\begin{array}{l}\text { Allocative inefficiency } \\
\text { contributes a large share of } \\
\text { cost inefficiency. Results } \\
\text { highlight the importance of } \\
\text { including environmental } \\
\text { variables in both technical } \\
\text { and allocative efficiency } \\
\text { analysis. }\end{array}$ \\
\hline $\begin{array}{l}\text { Haelermans et } \\
\text { al, (2012) }\end{array}$ & DEA & $\begin{array}{l}119 \text { Dutch } \\
\text { schools, } 2007\end{array}$ & $\begin{array}{l}\text { Inputs: Expenses per student. } \\
\text { Outputs: average national examination grades per school and the average student } \\
\text { achievement per school. } \\
\text { Second-stage variables: Profiling innovations; Pedagogic innovations; Process } \\
\text { innovations; Professionalization of the teacher innovations; Education chain } \\
\text { innovations; Total number of students; Location; Schools per governing body; } \\
\text { Degree of urbanization (in percent); Student/teacher ratio; and Percentage } \\
\text { students from disadvantaged neighborhoods. }\end{array}$ & $\begin{array}{l}\text { Descriptive analysis, } \\
\text { local linear regression } \\
\text { estimation and } \\
\text { nonparametric naïve } \\
\text { bootstrap procedure }\end{array}$ & $\begin{array}{l}\text { Results suggest that } \\
\text { innovation positively } \\
\text { influences school } \\
\text { performance and that the } \\
\text { effort of governments to } \\
\text { stimulate innovations in } \\
\text { education, and the effort of } \\
\text { schools to implement these } \\
\text { innovations, is not in vain. }\end{array}$ \\
\hline
\end{tabular}




\begin{tabular}{|c|c|c|c|c|c|}
\hline Author(s) & Methodology & Sample & Inputs, outputs, explanatory variables (if applicable) & Analytical technique & Main findings \\
\hline $\begin{array}{l}\text { Misra et al, } \\
(2012)\end{array}$ & SFA & $\begin{array}{l}90 \text { primary } \\
\text { and } 151 \\
\text { Mississippi } \\
\text { high schools, } \\
\text { 2005/06 }\end{array}$ & $\begin{array}{l}\text { Inputs: Total area of a school in square feet/total students; Total general } \\
\text { expenditure including school maintenance cost and other supplies in dollar/total } \\
\text { students; Total text book and instructional expenditure in dollar/total students } \\
\text { Mean number students per teachers in a school; and Mean number of students per } \\
\text { staff in a school. } \\
\text { Outputs: Average percentage of Mississippi Curriculum Test scores or Percent of } \\
\text { students passed in Subject Area Test Program. } \\
\text { Environmental variables: Principal's race; Principal's gender; Mean number of } \\
\text { staff; Percentage of staff that is black; Percentage of non-teaching staff that is } \\
\text { female; Mean number of teachers; Percentage of teachers that is black; } \\
\text { Percentage of teachers that is female; Mean number of years experience; } \\
\text { Percentage of teachers with master degree; Mean number of students in school; } \\
\text { Percentage of students that is black; Percentage of students receiving free lunch; } \\
\text { School Location Dummy; and School competition index. }\end{array}$ & $\begin{array}{l}\text { Descriptive analysis, } \\
\text { maximum likelihood }\end{array}$ & $\begin{array}{l}\text { The effect of competition } \\
\text { from private schools is } \\
\text { significant for Primary } \\
\text { Schools and High Schools. }\end{array}$ \\
\hline $\begin{array}{l}\text { Agasisti } \\
\text { (2011) }\end{array}$ & DEA & $\begin{array}{l}\text { Italian schools } \\
\text { (sample size } \\
\text { unknown), } \\
2006\end{array}$ & $\begin{array}{l}\text { Inputs: proportion of computers connected to the web as a proxy for the quality of } \\
\text { school's facilities; students' average socio-economic status as a measure of the } \\
\text { highest educational level and highest occupational status of parents. } \\
\text { Outputs: student achievement. } \\
\text { Second-stage variables: a set of dummies for schools located in the Southern, } \\
\text { Central and Isles part of Italy, two dummies (either small city or large city), two } \\
\text { dummies for academic schools and technical ones compared against the vocational } \\
\text { schools, a dummy for private schools, size and class size (student numbers), } \\
\text { percentage of girls, parental pressure provided by school head teachers, who } \\
\text { reported whether parents put pressure on school to pursue higher achievement. }\end{array}$ & $\begin{array}{l}\text { Descriptive analysis } \\
\text { and second-stage Tobit } \\
\text { regression analysis. }\end{array}$ & $\begin{array}{l}\text { When analyzing the role of } \\
\text { competition on schools' } \\
\text { performance, the functional } \\
\text { form of the relationship } \\
\text { between the two variables } \\
\text { matter. }\end{array}$ \\
\hline $\begin{array}{l}\text { Lewis et al, } \\
\text { (2011) }\end{array}$ & $\begin{array}{l}\text { Cost } \\
\text { efficiency } \\
\text { (SFA) }\end{array}$ & $\begin{array}{c}554 \\
\text { Indonesian } \\
\text { schools, } 2006\end{array}$ & $\begin{array}{l}\text { Inputs: Numbers of teachers; school location; total school costs; household head } \\
\text { education and household per capita expenditure (as a proxy for income). } \\
\text { Prices: Teacher wage rate and Government's geographic price index as a proxy } \\
\text { for other prices. } \\
\text { Outputs: Number of enrolled students; student test scores; and pass rate. } \\
\text { Environmental variables: Teacher absentee rates and teacher supply index. }\end{array}$ & $\begin{array}{l}\text { Descriptive analysis, } \\
\text { OLS and SFA } \\
\text { maximum likelihood }\end{array}$ & $\begin{array}{l}\text { Results suggests funding } \\
\text { does influence school } \\
\text { performance and public } \\
\text { primary education is } \\
\text { delivered inefficiently }\end{array}$ \\
\hline
\end{tabular}




\begin{tabular}{|c|c|c|c|c|c|}
\hline Author(s) & Methodology & Sample & Inputs, outputs, explanatory variables (if applicable) & Analytical technique & Main findings \\
\hline $\begin{array}{l}\text { Alexander et } \\
\text { al, (2010) }\end{array}$ & DEA & $\begin{array}{c}324 \mathrm{New} \\
\text { Zealand } \\
\text { Schools, } 2001\end{array}$ & $\begin{array}{l}\text { Inputs: Number of fulltime equivalent teachers; Number of teacher aides; Year } 13 \\
\text { student roll; Year } 12 \text { student roll; Year } 11 \text { student roll; Number of students in other } \\
\text { years; Administration expenses; Expenditure on learning resources; Depreciation } \\
\text { expenses; Expenditure for raising local funds; Property management expenses. } \\
\text { Outputs: Number of students passing bursary with minimum 4C or better grade; } \\
\text { sum of marks of students passing school certificate examination; number of } \\
\text { students leaving school with a 6th Form certificate. } \\
\text { Second-stage variables: Socio-economic environment index; School size; School } \\
\text { size squared; Percentage of teachers with } 5 \text { or more years of teaching; Percentage } \\
\text { of teachers teaching core subjects with at least 2nd year university qualifications; } \\
\text { State-owned school; Composite school (years } 1-13 \text { ); Secondary school (years 7- } \\
\text { 13); Secondary urban school; Minor urban school; Rural school; Boys' school; } \\
\text { Girls' school. }\end{array}$ & $\begin{array}{l}\text { Descriptive analysis } \\
\text { and second-stage } \\
\text { bootstrap regression } \\
\text { analysis. }\end{array}$ & $\begin{array}{l}\text { Results suggest that school } \\
\text { type and teacher quality } \\
\text { affects school efficiency. }\end{array}$ \\
\hline $\begin{array}{l}\text { Conroy and } \\
\text { Arguea } \\
(2008)\end{array}$ & SFA & $\begin{array}{c}\text { 1,256 Florida } \\
\text { schools, } \\
1997 / 98\end{array}$ & $\begin{array}{l}\text { Inputs: Interaction (mobility of students } \times \text { absenteeism rate); crime-violence; rate } \\
\text { of suspensions or expulsions; rate of promotion of students; ratio of free-lunch } \\
\text { eligible students; parent teacher organisation/association (dummy variable); } \\
\text { regional dummies. } \\
\text { Outputs: Florida Comprehensive Assessment test scores for maths and reading. } \\
\text { Second-stage variables: Teachers' years of experience; interaction (per pupil } \\
\text { expenditures } \times \text { free lunch eligibility); proportion of black students; proportion of } \\
\text { students with limited English proficiency; percentage of students with disabilities; } \\
\text { mobility of students; ratio of gifted students; interaction (parent teacher } \\
\text { organisation/association } \times \text { free lunch eligibility); southern region indicator } \\
\text { (dummy). }\end{array}$ & $\begin{array}{l}\text { Descriptive analysis, } \\
\text { second-stage maximum } \\
\text { likelihood (SFA) }\end{array}$ & $\begin{array}{l}\text { Schools were not operating } \\
\text { at efficient levels. High } \\
\text { levels of inefficiency for } \\
\text { reading due to increased } \\
\text { resources on teaching } \\
\text { English to non-native } \\
\text { speakers. }\end{array}$ \\
\hline $\begin{array}{l}\text { Cordero- } \\
\text { Ferrera et al, } \\
(2008)\end{array}$ & DEA & $\begin{array}{l}80 \text { Spanish } \\
\text { schools, } \\
2001 / 02\end{array}$ & $\begin{array}{l}\text { Inputs: Total number of teachers in the school and total current cost per } \\
\text { student excluding school personnel costs. } \\
\text { Outputs: average mark of pupils passing the university entrance exam and } \\
\text { percentage of pupils who pass the exam compared to those enrolling in a } \\
\text { university courses. } \\
\text { Second-stage variables: Three components comprising of the different } \\
\text { combinations of the following variables (Pupils who passed all their subjects last } \\
\text { year; pupils who have never repeated a year; pupils who passed all subjects } \\
\text { between June and September last year with high marks; pupils who studied for } \\
\text { more than } 10 \text { hours a week; pupils wishing to study at university; pupils whose } \\
\text { parents have confidence in their academic success; pupils whose parents have } \\
\text { high incomes; pupils whose father has a university education; pupils whose } \\
\text { mother has a university education; pupils whose father is a qualified professional; } \\
\text { pupils whose mother is a qualified professional). }\end{array}$ & $\begin{array}{l}\text { Descriptive analysis, } \\
\text { second-stage Tobit } \\
\text { regression (DEA) and } \\
\text { Tobit bootstrap model }\end{array}$ & $\begin{array}{l}\text { Choice of model dependent } \\
\text { on the specific objectives } \\
\text { and the characteristics of the } \\
\text { available sample. } \\
\text { Bootstrapping avoids } \\
\text { problems of bias in the } \\
\text { estimations. }\end{array}$ \\
\hline
\end{tabular}




\begin{tabular}{|c|c|c|c|c|c|}
\hline Author(s) & Methodology & Sample & Inputs, outputs, explanatory variables (if applicable) & Analytical technique & Main findings \\
\hline $\begin{array}{l}\text { Rassouli- } \\
\text { Currier } \\
(2007)\end{array}$ & DEA & $\begin{array}{l}\text { 354 Oklahoma } \\
\text { schools, 1996- } \\
99\end{array}$ & $\begin{array}{l}\text { Inputs: Instructional expenditure per student (\$) and noninstructional expenditure } \\
\text { per student (\$). } \\
\text { Outputs: ITBS for grade 3; CRT for grade 5; ITBS for grade 7; CRT for grade 8; } \\
\text { CRT for grade 11; and Average ACT scores for all seniors in the district. } \\
\text { Second-stage variables: Percentage of minority students; average household } \\
\text { income; assessed value of property within the boundaries of the district per } \\
\text { student; poverty rate; percentage of adults age } 20+\text { with education beyond high } \\
\text { school diploma; percentage of Students in Special education; percentage of } \\
\text { students eligible for reduced cost or free lunch; student/teacher ratio; average } \\
\text { salary per full-time equivalent teacher (\$); percentage of teachers with advanced } \\
\text { degree; and average experience of teachers (year). }\end{array}$ & $\begin{array}{l}\text { Descriptive analysis, } \\
\text { Tobit regression and } \\
\text { Spearman rank } \\
\text { correlation }\end{array}$ & $\begin{array}{l}\text { Socioeconomic factors are } \\
\text { the primary reasons for the } \\
\text { variation in the efficiency of } \\
\text { the Oklahoma school } \\
\text { districts. }\end{array}$ \\
\hline $\begin{array}{l}\text { Kantabutra } \\
\text { and Tang } \\
(2006)\end{array}$ & DEA & $\begin{array}{l}456 \text { Thailand } \\
\text { schools, } 2003\end{array}$ & $\begin{array}{l}\text { Inputs: Teacher-student ratio and proportion of students not from low-income } \\
\text { families. } \\
\text { Outputs: Average national test scores; number of students who passed their } \\
\text { grades after first and second year; and number of graduates. } \\
\text { Second-stage variables: Average number of students per class (class size) and } \\
\text { Total number of students enrolled (school size) }\end{array}$ & $\begin{array}{l}\text { Descriptive analysis, } \\
\text { Mann-Whitney } \\
\text { statistical test and Tobit } \\
\text { regression }\end{array}$ & $\begin{array}{l}\text { School size has a positive } \\
\text { effect on both urban and } \\
\text { rural schools. Class size has } \\
\text { a positive effect on urban } \\
\text { schools and a negative one } \\
\text { on rural schools }\end{array}$ \\
\hline
\end{tabular}


Table II.

Descriptive statistics of the inputs, outputs, and environmental variables

\begin{tabular}{clrrrr}
\hline & Variable & \multicolumn{1}{c}{ Mean } & \multicolumn{1}{c}{ Min. } & Max. & Std. Dev. \\
\hline \multirow{5}{*}{ Inputs } & & & & \\
& Capital expenditure per FTE student (\$) & 155077.1 & 20571.9 & 1360324.1 & 104057.4 \\
& FTE teaching staff per FTE student (\$) & 0.06 & 0.05 & 0.17 & 0.01 \\
& & & & & \\
Outputs & Year 5 NAPLAN score (n) & 477.0 & 371.2 & 562.8 & 31.0 \\
& Year 7 NAPLAN score (n) & 525.8 & 439.6 & 631.6 & 30.1 \\
\hline \multirow{5}{*}{ School } & & & & \\
environment & ICSEA (index) & 990.1 & 730.0 & 1222.0 & 76.6 \\
& Class size (n) & 24.1 & 11.0 & 30.0 & 2.9 \\
& Postgrad (ratio) & 0.2 & 0.0 & 1.5 & 0.2 \\
& Development (\$) & 866.3 & 50.5 & 4179.8 & 593.6 \\
& Know assessment (\%) & & & & \\
& Use computers (\%) & 94.0 & 79.8 & 100.0 & 4.0 \\
& English (\%) & 95.6 & 79.6 & 100.0 & 3.6 \\
& Maths (\%) & 95.2 & 76.3 & 100.0 & 3.6 \\
Learning & Opinion (\%) & 95.0 & 80.0 & 100.0 & 3.7 \\
Schoolwork (\%) & 90.5 & 71.0 & 100.0 & 5.8 \\
& Challenge (\%) & 95.7 & 71.4 & 100.0 & 3.7 \\
& Explain (\%) & 96.3 & 75.0 & 100.0 & 3.3 \\
& Help (\%) & 95.8 & 72.7 & 100.0 & 3.5 \\
& Motivate (\%) & 95.6 & 81.8 & 100.0 & 3.4 \\
& Feedback (\%) & 97.2 & 83.9 & 100.0 & 2.6 \\
& Variety (\%) & 95.3 & 76.5 & 100.0 & 3.6 \\
& & 96.2 & 79.1 & 100.0 & 3.2 \\
\hline
\end{tabular}

\section{Figure 1.}

Correlation between efficiency scores and performance
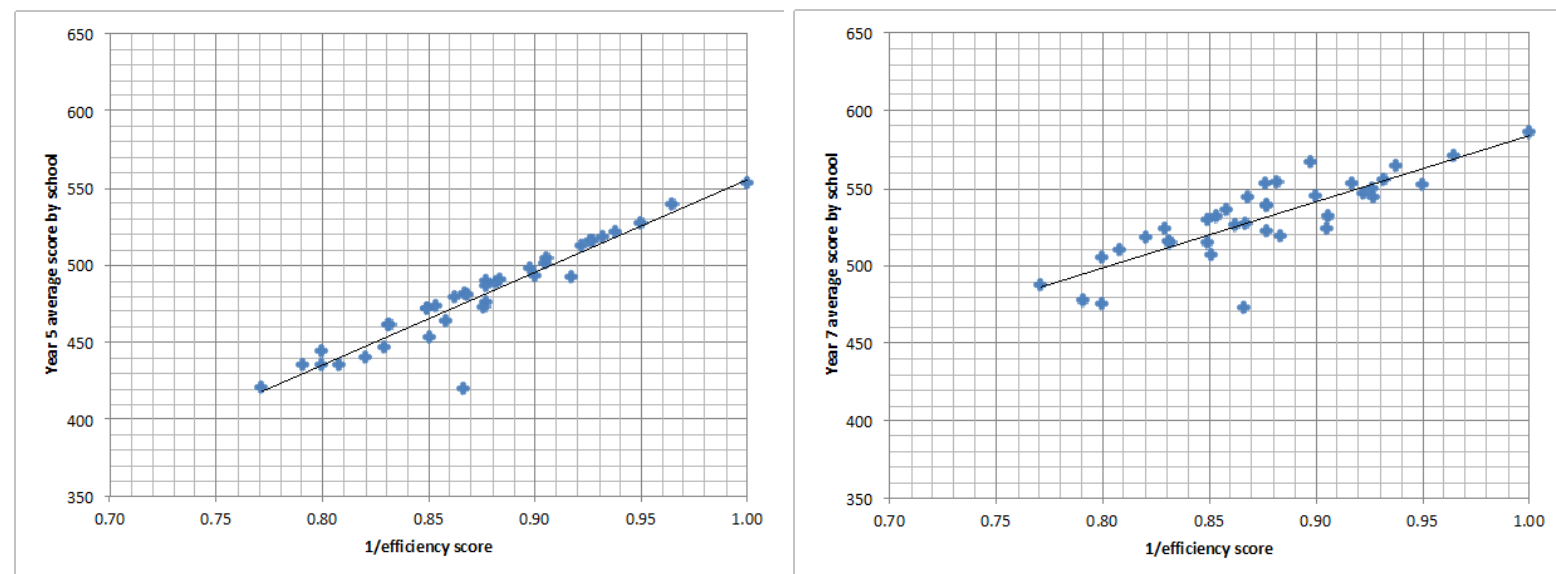

Note: Output-oriented efficiency scores range from 1.000 to $\infty$. For the rank correlation calculations, we use the reciprocal of the efficiency scores so that the scores lie between 0 and 1 . 
Table III.

Truncated regression results

\begin{tabular}{lcrr}
\hline Variable & Coefficient & \multicolumn{2}{c}{ Confidence Interval } \\
& & Lower bound & Upper bound \\
\hline Constant & 2.0646300 & 1.8896050 & 2.2430980 \\
\hline ICSEA (index) & $-0.0008271^{*}$ & -0.0008887 & -0.0007700 \\
Class size (number) & 0.0011484 & -0.0001929 & 0.0025087 \\
Postvgrad (ratio) & 0.0041629 & -0.0138577 & 0.0220691 \\
Development & -0.0000013 & -0.0000081 & 0.0000053 \\
Know assessment & -0.0013175 & -0.0026860 & 0.0001042 \\
Use computers & 0.0009596 & -0.0003755 & 0.0022972 \\
English & -0.0011138 & -0.0028055 & 0.0005977 \\
Maths & 0.0011626 & -0.0003666 & 0.0026474 \\
Opinion & $-0.0011614^{*}$ & -0.0021575 & -0.0001197 \\
Schoolwork & -0.0003444 & -0.0018198 & 0.0011612 \\
Challenge & 0.0004341 & -0.0016019 & 0.0022867 \\
Explain & $-0.0020669^{*}$ & -0.0038065 & -0.0003266 \\
Help & 0.0012232 & -0.0006351 & 0.0030529 \\
Motivate & -0.0006431 & -0.0026516 & 0.0013423 \\
Feedback & -0.0000928 & -0.0016758 & 0.0014478 \\
Variety & $0.0018338^{*}$ & 0.0000105 & 0.0036303 \\
\hline * Significant & &
\end{tabular}

${ }^{*}$ Significant at the $5 \%$ level; total number of iterations $=2,000$.

Note: A positive (negative) sign indicates an increase (decrease) in inefficiency. 